\title{
TEXTOS INEDITOS DE JOAQUIM DE CARVALHO SOBRE TEIXEIRA DE PASCOAES
}

(apresentados por Joaquim de Montezuma de Carvalho)

Como colaboração inicial a prestar à revista LETRAS, do Sector de Ciências Humanas, Letras e Artes da Universidade Federal do Paraná, tenho o prazer de divulgar alguns textos inéditos de meu falecido pai, prof. Joaquim de Carvalho, sobre um grande campeão da poesia portuguesa, Teixeira de Pascoaes.

O Brasil conhece profundamente a Luis de Camões, Antero de Quental e Fernando Pessoa, mas ignora quase a Teixeira de Pascoaes. No Brasil não há obras editadas do poeta do Marão. Apenas circula, a antologia 'Teixeira de Pascoaes-Poesia', ordenada por Jorge de Sena, ${ }^{\prime}$ autor da respectiva 'Apresentação' (16 pgs.). Não se pode dizer que Pascoaes entrou com o pé esquerdo no Brasil. Essa brilhante apresentação de Jorge de Sena, outro poeta e ensaista cuja fama cresce dia a dia, é mesmo um dos mais notáveis éstudos que até hoje se dedicaram a Pascoaes.

A admiração de Jorge de Sena por Camões e Fernando Pessoa é um fato de todos conhecido. Menos saliente ou evidenciado, a admiração que nutre por Pascoaés. Nessa 'Apresentação' emite desde logo este juizo que só se reserva para os gigantes: "Traduzido na Espanha (onde exerceu enorme influência), na França, na Holanda, na Alemanha e na Hungria, Teixeira de Pascoae's foi um dos raros escritores verdadeiramente grandes da língua portuguesa a vencer as barreiras impostas pelo nosso provincianismo cultural e pela indiferença imperialística das grandes culturas estabelecidas" "

1 SENA, Jorge de. Teixeiro do Pascoes; poesia. Rio de Janciro, Agir, 1965. 98 p. (Nossos Clássicos, B0).

2 SENA, p. 93-4.

3 MONTElRo, Antonio Casuis, comp. Poesia - Fornando Pessoa. 2. ed. Lisboa, Ed. Con. fluencis, 1945. 
Este lapidar juizo há que uní-lo a um outro de Adolfo Casais Monteiro e que abre a sua 'Introdução' ao livro por si organizado 3 O juizo de Casais Monteiro é o seguinte: - "Na mais alta linha de cumes da nossa poesia, as altitudes assinaladas por quatro poetas formam entre si uma cadeia distinta $e, c o m$ as figuras subsidiárias que as prolongam, se thes poderia chamar, usando ainda o vocabulário geográfico, um verdadeiro sistema orográfico. E tal 'sistema' com maior relevo o veremos recortar-se sobre a paisagem geral da nossa literatura se atendermos a que esses quatro poetas são precisamente, senão os maiores, pelo menos quatro dos maiorés que têm nascido entre nós: Camões, Antero, Pascoaes e Fernando Pessoa".

A meu pai ouvi muitas vezes dizer que só existiam quatro poetas e'm Portugal que à sensibilidade tinham aliado uma transcendente intuição filosófica: essses quatro poetas eram Camões, Antero, Pascoaes e Fernando Pessoa. Os tais quatro cumes da nossa cordilheira poética, tão soberanos e inacessíveis como o Himalaia, o Aconcágua, - Monte Branco ou o Guadarrama. Os tais cumes do 'sistema' geográfico apontado por Casais Monteiro. Voltando ao juizo de Jorge de Sena. Num artigo sobre Pascoaes que lhe pedi em 1951, para o semanário Via Latina, órgão da Associação Acadêmica de Coimbra, Jorge de Sena confidenciou isto: - "Para todas estas dificuldades da poesia de Pascoaes é que eu quereria chamar as atençōes, inclusive a minha. Porque eu tenho uma grande divida para com o Poeta, ou ele a tém para comigo. Foi a leitura, feita ao sair da infância, da sua 'Terra Proibida' que me abriu os sentidos para uma coisa que eu não sabia tão grande: a 'terra proibida' da Poesia".

Nesse maio de 1951, Jorge de Sena explicando-nos, a nós estudantes universitários de Coimbra, o extremamente difícil falar de um poeta camo Teixeira de Pascoaes, também nos explicava que nascera poeta através do deslumbramento auroral que obtivera com Pascoaes e a sua leitura logo nos anos mais verdes.

Só um grande poeta é capaz realmente de fecundar outros espiritos, iluminar-lhes a vocação primogénita, revelar-lhes um destino que estava escondido. Como Pascoaes era esse astro de primeira grandeza e luz, logo as trevas se desfizeram e o infante Jorge de Sena nasceu para a palavra poética.

Ao comum leitor brasileiro que só ouve mencionar Camões ou Pessoa, Antero de Quental ou Guerra Junqueiro, era necessário frisar a estimativa destes juizos para que alcance até que ponto anda injusto com o desconhecimento de um poeta tão rico e profundo, tão furiosamente instintivo e espiritual como é Teixeira de Pascoaes.

4 MONTEIRO, P. 7. 
Esse brasileiro desatento nem sequer observa que 0 seu tão apreciado Fernando Pessoa é um poeta que nasce fascinado por Pascoaes e que para sé libertar da sua poderosa tutela até teve de criar um personagem anti-Pascoaes, precisamente o seu heterónimo Alberto Caeiro. E teve de inventar ou recriar o futurismo e de'sdobrar-se em outras tendências para ter algum futuro. Porque a presença de Pascoaes o esmagava e a sua rebeldia foi a forma de não the ser indiferente. A génese de Fernando Pessoa terá sempre de descobrir-se através de Pascoaes. Não é um discípulo que o segue. É um discípulo que se insurge. Da sua rebelião fez a sua révolução estética e normativa. Algo de idêntico se passou entre Karl Marx e Hegel: não são parecidos e, todavia, parecem-se: Seria um erro crasso dizer que Marx nada deve a Hegel ou Fernando Pessoa a Teixeira de Pascoaes só porque o 'sentido' das suas obras é diferente. Ele é diferente mas a custa de transpor as influencias para outra dimensão emancipadora. Um discipulo sem imaginação é sempre um discipulo. Um discípulo com imaginação funda uma nova ordem de valores, passa de discipulo a mestre. Foi o caso de Fernando Pessoa em relação a Teixeira de Pascoaes. Venceu as influências, superando-as. Mas nem por isso tais influências deixam de ser o motor da mutação.

No apêndice da antologia Teixeira de Pascoaes-Poesia que Jorge' de Sena publicou no Brasil figuram, a finalizar um julgamento crítico, uma série de juízos sobre o poeta metafísico de Amarante e, por ser metafísico, quase sem pátria local. Nessa série de juizos há pensamentos de Miguel de Unamuno, Fernando Pessoa, Georges Le Gentil, José Régio, Joaquim de Carvalho, Joāo Gaspar Simões, Adolfo Casais Monteiro, Antonio José Saraiva e Oscar Lopes, Jorge de Sena.

O pensamento de Joaquim de Carvalho é o seguinte: - "A sua original peculiaridade logo ressalta do teor das imagens e das meláforas e mais se destaca quando se compara aos mundos poéticos de alguns coetâneos, notadamente de Antero de Quental, de Eugenio de Castro e de Fernando Pessoa. O mundo poético de Antero é, por excelência, o mundo dos problemas especificamente humanos, das lutas pelo Direito e pela Justiça, dos destinos últimos da consciência moral, das dúvidas metafísicas; o de Eugénio de Castro, no polo oposto, é o mundo construído e expresso somente com dados sensoriais, sob o compasso do bom-senso - dondé uma poesia de lavrante, alheia à problemática humana mas rica de tonalidades pictóricas, de ritmo musical, de modelação plástica; e o de Fernando Pessoa, um mundo solipsista, de quem somente se reconhecia no próprio ev é no complexo subtil dos estados e das relações subjetivas de que se apercebia. (...) No íntimo, o mundo poético de Pascoaés era um mundo refletido, estante e não deviente, no qual toda a concretização e toda a fenomenologia sensível the apareciam como 'sombras' da 
realidade autêntica, muda, silenciosa, imóbil. Daqui, a sensação genérica de um mundo, do qual o seu espirito era a um tempo criador e adāo, e uma poesia mundificante e nāo humanizante, essencialista, e não presencista nem futurante, tanto mais que a sua sensibilidade não apreendia o Tempo como mudança e alteração, mas como lugar - onde do ontem, do hoje e do amanhã. ${ }^{3}$

Este pensamento coligido por Jorge de Sena foi extraido do prefácio de meu pai à obra 'Epistolário Ibérico - Cartas de Pascoaes e Unamuno" que eu lancei durante a minha permanência em Angola, livro que inclui ainda um outro prefácio do saudoso Doutor Manuel Garcia Blanco, professor da Universidade de Salamanca, e se completa com uma 'nota final' de minha própria autoria.

1951 foi o ano da homenagem nacional a Teixeira de Pascoaes. Essa homenagem nasceu em grandé parte de minha iniciativa. Era o tributo da Academia de Coimbra, erguendo ao alto nos seus braços juvenis um altíssimo poeła e que também fôra estudante de Direito da sua Universidade.

Na sua antologia das Líricas Portuguesas 5 José Régio referiu-se a essa festa nacional: [T. de Pascoaes]. Recebeu, pouco antes de morrer uma entusiástica homenagem dos estudantes de Coimbra, que assim se honraram honrando o maior poeta vivo do seu tempo". "

No dia da homenagem - 12 de maio de 1951 - foi distribuido - livro que eu organizara. i

O formoso livro, com ilustrações dos artistas Carlos Carneiro, Antonio Duarte, Júlio, João Luís, João Maria e Tóssan, trazia um pequeno prefácio de minha autoria, seguindo-se depois as colaboraçōes de' Adolfo Casaes Monteiro, Afonso Duarte, Albano Martins, Albert Vigoleis Thelen, Alberto de Monsaraz, Alberto de Serpa, Alberto Uva, Alexandre de Córdova, Alexandre Pinheiro Torres, Aloysio dé Castro Américo Cortez Pinto, Américo Durão, Amorim de CarvaIho, Anthero de Figueiredo, António Botto, António Correia d'Oliveira, António de Cértima, António de Sousa, Antonio Luís Moita, Antonio Manuel Couto Viana, Antonio Navarro, Antonio Noriega Varela, padre Antonio P. Dias de Magalhāes S.J., Antonio Quadros, Antonio Sérgio, Antunes da Silva, Armando Cortes - Rodrigues, Armando Ranito, Armindo Rodrigues, Augusto Casimiro, Aureliano Lima, Branquinho da Fonseca, Cabral do Nascimento, Câmara Reys, Campos de Figueiredo, Fernando Lopes Graça, Carlos Gabriel, Daniel Filipe, David

5 REGIO, José, comp. Líricas portuguesss. I.“ sér. 3 ed. Lisbos, Portugália, 1959. 340 p.

6 REGIO, p. 340.

7 CARVALHO, Joaquim de Montezuma, comp. A. Teixeira de Pascoases. Coimbra, Academia de Coimbro, $1955.152 \mathrm{p}$. 
Mourão - Ferreira, Dictinio de Castillo - Elejabeytie, Edmundo de Bettencourt, Eduardo Victor, Egas Moniz, Egito Gonçalves, Eug'enio de Andrade, Fausto José, Fernanda Botelho, Fernando de Paços, Ferreira de Castro, Hernâni Cidade, Ilídio Sardoeira, Jacinto do Prado Coelho, Jaime Cortesão, João de Barros, João de Castro Osório, João de Deus Ramos, João Dradé Correia, João José Cochofel, João Patrício, Joaquim Namorado, Jorge de Lima, Jorge de Sena, José Fernandes Fafe, José Ferreira Monte, José Gomes Ferreira, José Marinho, José Régio, Leonor de Almeida, Luís de Almeida Braga, Luís de Macedo, Luís Ribeira Sêca, Manuel Amaral, Manuel Bandeira, Manuel Dias da Fonseca, Manuel Lopes da Silva, Manuel Mengo, Maria Helena, Mário Beirão, Mário Dínísio, Miguel Torga, padre Moreira das Neves, Natércia Freire, Nuno de Sampaio, Pedro Homem de Melo, Ribeiro Couto, Rui Galvão de Carvalho, Sant'Anna Dionísio, Saul Dias, Sebastião da Gama, Sidónio Muralha, Sophia Andresen, Talhoff, Tomás Kim, Vasco de Lima Couto, Vitorino Nemésio, completando-se o elenco com alguns estudantes a saber: Adriano de Faria, Afonso de Moura Guedes, Bastos Raposo, Francisco Correia, Jacinto Soares de Albergaria, João Maria, Joaquim de Montezuma de Carvalho, Jorge Nemésio, M. Ortigão dé Oliveira e M. Vilhena de Carvalho.

O Brasil estivera presente através dos poetas Aloysio de Castro, Jorge de Lima, Manuel Bandeira e Ribeiro Couto. Tenho de lembrar - belo 'Improviso' que Manuel Bandeira nos enviou então (Rio de Janeiro, 11 de abril de 1951) para o completíssimo livro de homenagem:

Glória aos poetas de Portugal.

Glória a D. Dinis. Glória a Gil

Vicente. Glória a Camões. Glória

a Bocage, a Garrett, a João

de Deus (mas todos são de Deus,

e há um santo: Antero de Quental).

Glória a Junqueiro. Glória ao sempre

Verde Cesário. Glória a António

Nobre: Glória a Eugénio de Castro.

Glória a Mário de Sá Carneiro.

A Pessoa e seus heterónimos.

A Camilo Pessanha. Glória

a tantos mais, a todos mais.

Glória a Teixeira de Pascoaes.

Foi o poema que todos sabiamos de cor, nessa tarde de sábado de $1 .^{\circ}$ de maio de 1951, no romântico ambiente do Parque de Santa Cruz, onde a festa estudantil e nacional decorreu com a presença do Poeta e toda a Coimbra. Lembro que entre a assistência se viam 
os irmãos, irmãs e sobrinhos do homenageado, Joaquim de Carvalho, os poetas Miguel Torga e Campos de Figueiredo, o escultor António Duarte, o pintor Guilherme Filipe, etc.

Estávamos em pleno fascismo-salazarista e Teixeira de Pascoaes odiava essa polífica repressiva, sem ideal violadora constante dos direitos democráticos. Pascoaes refugiara-se na sua, Quinta de São João de Gatão, propriamente no lugar dito Pascoaes, a poucos quilometros de Amarante. Preferia essa solidão com a natureza à outra mais medonha de Lisboa, com 'pides' por todas as mesas de café, espiando e ouvindo conversas alheias. O regime' corporativista nunca The tecera elogios, enterrara-o já em vida. Para o salazarismo, o poeta nacional fôra Antonio Correia d'Oliveira com suas quadrinhas de sabor popular-populista. Tão miope era o 'talento' estético do salazarismo que atribuiram um segundo premio a Fernando Pessoal Para Pascoaes nem premio nem fala. Era sistematicamente preterido. Simplesmente não se invocava seu nome...

Entre os papéis inéditos das 'memórias' de meu pai encontro Ésta anotação: - "12 de maio - 1951. Festa dos estudantes a T. de Pascoaes, na Quinta de Santa Cruz: tarde primaveril, ensolada, serena, radiante de força criadora. Ausência da Universidade, da Academia de Clências de Lisboa, da Igreja, do Exército, dos 'Diários de Notícias', de tudo o que foi, é e poderá vir a serr o Estado Novo. Véspera do teste oficial de Fátima. Os estudantes bem, sem Espetáculo nem imporfunices. Sóbrios e românticos. Nunca se fez coisa idêntica, a não ser na tardé em que os do Romantismo foram à Lapa dos Esteios por Antonio Feliciano de Castilho. Tarde promissora de novodia - do Dia que ansiosamente espero e talvez já não veja".

Efetivamente, Joaquim de Carvalho já não pôde enxergar o 25 de abril de 1974. Mas sabia que haveria de verificar-se uma outra primavera de pleno sentido, que viesse dé novo restituir ao povo português a sua alegria perdida.

Aquela tarde de Coimbra em honra de Pascoaes jó prefigurava - Portugal que estava por nascer. Joaquim de Carvalho sentiu-o, porque há uma hora em que o homem não se vende: a da sua juventu. de. Ainda bem que deixou essa anotação solta para as suas 'memórias'. Assinalou com isso uma das páginas mais empolgantes da juventude portuguesa que não se deixava amordaçar pelos falsos valores que a ditadura, com todo o exclusivo poder da sua propaganda, procurava impingir. A homenagem era a um grande poeta limpo, liberal como os republicanos sabiam ser, partindo igualmente de uma juventude acadêmica ainda não corrompida, esperançada na renovação, desejosa de construir também um pais limpo. 
A festa coimbrã fôra precedida, um mês antes, pela que a cidade de Amarante tomara a iniciativa de realizar. Pascoaes nascera em Amarante, no ano de 1878. Nenhum outro valor, oriundo de Amarante, se podia comparar ao de Pascoaes. O dia 31 de março de 1951 foi a apoteose. Cerca das 10,30 o Presidente do Municipio de Amarante e numerosas individualidades, amigos e admiradores do autor de 'Sempre' dirigiram-se à Casa de Pascoaes e, após uma curta visita, formou-se um cortejo automobilístico, que se encaminhou para o Convento de São Gonçalo, onde, nas salas da Biblioteca Museu Municipal, se ia inaugurar uma Exposição Bibliográfica de Teixeira de Pascoaes. Viam-se ali expostas, como também tive a ocasiāo de presenciar, em duas amplas salas do arruinado edificio, as diferentes edições portuguesas e estrangeiras das obras de Pascoaes e críticas à sua obra. Além dum vasto documentário fotográfico, que acompanhava as várias fases da vida do escritor, encontravam-se, também, retratos assinados por Antonio Carneiro, Eduardo Malta, Columbano, Carlos Carneiro e outros, e um busto de autoria de Antonio Duarte. Em montras especiais viam-se, ainda, documentos de muito interesse para o estudo do poeta, dé personalidades de prestígio internacional como Bardiaeff, Unamuno, Ph. Lesbesgue, Holzner, Fernando Pessoa, etc., etc.

A seguir, no amplo salão do 'Amarante Cine Teatro', efetuou-se um almoço de homenage'm e de confraternização a que assistiram cerca de duzentos convivas. Presidiu o homenageado, tendo à direita o coronel Carvalho Lima (presidente do Municipio de Amarante), dr. José Falcão de Sousa e Castro, dr. Jaime Silva, dr. Ilídio Sardoeira, comandante Agatāo Lança $\epsilon$ eng. ${ }^{\circ}$ Nogueira Soares; e à esquerda, 0 prof. dr. Joaquim de Carvalho, dr. Barbosa da Cunha, ten-coronel Costa Santos, Peixoto e Cunha e Pedro Alvellos. Presentes estavam, também, os irmãos de Pascoaes, o poeta Alberto Serpa, etc. .

Durante o almoço recordo qué foram lidos telegramas de Egas Moniz, Maria Lamas, Ferreira de Castro, Antero de Figueiredo, Antonio Sérgio, José Régio, Sant'Anna Dionísio, Câmara Rey, Hernâni Cidade, José Marinho, Antonio Correia d'Oliveira, Mário Beirāo, etc.

Aos brindes usou da palavra meu pai, que começou por explicar que viera associar-se àquela homenagem por um imperativo de ordem intelectual. A sua admiraçāo por Teixeira de Pascoaes vinha da infância e crescera ao verificar que era um homem verdadeiramente superior como poeta, escritor e pensador e que, ao ver o interesse de universitários estrangeiros pela obra de Pascoaes, sentira qué era um dever ajudar a trazer para o primeiro plano da consciência nacional a admiração por tão grande fígura. Joaquim de Carvalho falou de improviso e nem sequer gravação se fez. Apenas me lembro desses 
tópicos. Mas as suas palavras empolgaram os convivas e tornaram os olhos do poeta brilhantes e húmidos.

Findo o almoşo de homenagem, por sugestão apresentada pelo comandante Agatão Lança, militar que foi sempre da oposição viva a Salazar, houve um passeio ao Marão, a imponente serra que tantas vezes o poetra cantara nos seus versos. Ascendeu-se à Pousada e aí houve um descanso com café, chá, wiskys, doces da região e a paisagem tonificante dessas serranias, tantas vezes percorridas por Camilo no tempo ido das diligências.

O Estado Novo havia povoado aqueles íngremes êrmos de matas e matas. Pinheiros e eucaliptos. Le:nbro a indignação de Pascoaes, dizendo: outrora o Marão era o que era, serras e serras sem uma árvore. Agora vestiram-no, tiraram-lhe a sua nudez masculina e afeminaram-no. O Marão hoje é uma mulher. Não se parece nada ao que foi.

Deixou-se a Serra e todos regressaram a Amarante. A noite, conforme o programa elaborado e largamente distribuido, realizou-se no 'Amarante Cine Téatro', com a casa cheia, um Sarau, o último ato da série de festejos que se tributavam a Pascoaes. Esse Sarau abriu precisamente com uma magistral palestra de meu pai, subordinada ao título: 'Teixeira de Pascoaes, Poeta e Pensador'.

Passaram lá muitos anos depois dessa emotiva noite de 31 de março de 1951. Com a mesma emoção com que escutei, então, a voz sábia e quente dé meu pai, hoje descubro entre seus papéis inéditos o texto dessa alocução. O seu texto não merece continuar nas sombras do anonimato. É bem digno de se tornar público e no Brasil. Os conceitos que Joaquim de Carvalho explanou são definições essenciais para a justa compreensão desse poeta, o mais filósofo de todos os poetas portugueses.

Eis o texto de autoria de Joaquim de Carvalho:

"Não vim até junto de vós para fazer o elogio de Teixeira de Pascoaes porque seria inoportuno, nem para discursar o que seria de mau gosto, nem mesmo para homenagear, o que quase seria ofensivo. Venho somente com o propósito de $m \in$ associar à vossa congratulação de conterrâneos do Poeta, por pensar que os motivos por assim dizer locais do vosso júbilo e do vosso reconhecimento contêm a significação embrionária de uma maneira de ser, de sentir e de conceber o mundo que constifui a sigla original de uma personalidade inconfundivel e ao mesmo tempo assinala uma das manifestações mais puras e perfeitas da própria essência do genio poético. Há, pois, para a festa que nos congrega motivos de júbilo local e razōes de aplauso universal. 
Os amarantinos têm justificada razão em radicarem o enlêvo e as transfigurações do vidente do 'Maranus' na terra e na paisagem que thes é nativa, assim como em verem analogia entre a subida do Marão e a ascenção das concepções do Pensador a planos cada vez mais elevados e significativos, em virfude de uma $\epsilon^{\prime}$ outra serem "um desvendar de novos horizontes que se afastam", no expressivo dizer do próprio Poeta.

Com efeito, não sei de outrem que com mais constância, proveito e vivezo se haja nutrido do localismo das sensações primigénias e da sedentariedade das suas vivências ambientais. Pelas raizes e pela créscença, creio que o vosso conterrâneo será enquanto se falar a nossa língua o Poeta e o Pensador de Pascoaes, de Riba-Tâmega e do Marão, dada a presença vivente e auroral, no seu mundo interior, de três componentes locais: casa em qué nasceu e lhe decorreu a existência, com a constelação de significados que o solar de familia tem nas gentes de Entre Douro e Minho; a aldeia em que tem habitado pelo eflúvio afetivo de certos comportamentos humanos, e, sobretudo, os vales e serranias circundantes, pela compenetração do seu ser profundo com a configuração e com a paisagem deste sítio da sua nascença, crescença e madurez.

O nomé literário do vosso conterrâneo é, pois, o símile adequado à sua constifuição terrantês e ambiental; mas se isto é exato, não é menos exato que o alto espírito que viu a luz em Pascoaes e do torrão natal nutriu o pensamento criador, se transfigurou em Poeta e Pensador sem apoio telúrico, sem liames terricolas e sem limites particularistas. E que a casa de família, o torrão natal e, porventura, o conviver aldeão, assinalam somente o lugar onde o seu genio recoIheu as intuições primeiras e o seu pensamento se situou e se reconheceu a si mesmo na revelação de imagens aurorais e, por assim dizer, funcionais. Não constituiram nunca, própria e exclusivamente, o destino do seu sentir e do seu pensamento, porque o destino do seu sentir e do seu pensar, desde os verdes juvenis dos quinze anos, se afastou do presente e do local em busca do ausente $\epsilon$ do distante.

Os seus conterrâneos podem pensar, e não sem razão, que a gestação espiritual do Poeta, não é compreensível sem o isolamento no lugar de Pascoaes. E podem pensá-lo, porque viver isolado equivale quase sempre a perder o contato com o acontecer determinativo de açōes, de reaçōes e de realizaçōes, e a encher a existência com a entrega total à intimidade. Sem o isolamento físico não é realmente explicáve:' a gestação do mundo interior do Poeta da 'Vida Etérea' e de 'As Sombras', mas tenho igualmente por verdade, e principalmente por mais significativo e relevante, que a função capital do isolamento consistiu em proporcionar ao Poeta a intuição de que viver 
é entrar em relação com o latente e com o que transcende o que se mostra com ostensiva presença $\epsilon$ atualidade.

Com efeito, a obra de Teixeira de Pascoaes nasceu no isolamento, isto é, na intimidade da consciência consigo mesma, mas isolamento e intimidade nāo querem dizer soledade.

Não o dizem para o comum das almas que se depuraram no exercício da vida interior e muito menos o dizem para o Poeta do 'Regresso do Paraiso', que é o poema da consciência que sé sente religada ao espiritual e no invisivel e no inefável firma a certeza de que é destino humano o aniquilamento do Nada. Passo algum da obra do Poeta e do Escritor dá a sénsação do gozo do instante e muito menos o egotismo da consciência repleta e satisfeita; e se algo carateriza a sua evasão do presente e do atual é ela dar-se sob a instância do ausente $\epsilon$ do distante e acompanhar-se do sentimento da realidade presencial de existências imateriais, que dão ao Mundo sentido espiritual.

E este sentimento de compresença e da convivência com o imaterial que a meu ver caracteriza a obra de Teixeira de Pascoaes e define a sua atitude de poeta-filósofo. Esteticamente, o primado deste sentimento determinou que o Poeta não haja visto o Mundo como espetáculo de cor, de ritmo ou dé formas esculturais, e conceptualmente o haja considerado independentemente das categorias da racionalidade, como intuiçāo e apreensão de realidades imateriais, destituídas de objetividade sensível e de causalidade perceptivel.

Quer isto dizer, por outras palavras, que Teixeira de Pascoaes é poeta por determinação intrinseca da sua própria constituição, e não pe!o enlevo que os objetos lhe causem. Perante os objetos, o seu espírito jamais tomou a atitude espetacular, descritiva, circundante. Sente-os como algo que se introvertem no seu próprio ser, porque sāo portadores de uma essência imaterial e pura.

No âmago do ato Poético dá-se sempre a entrega do espirito a algo que o enleva e transcende, mas o que individualiza a entrega da criação poética de Teixeira de Pascoaes é ser univoca e não dispersiva $\epsilon$ impressionista. O poeta de constituiçāo impressionista vive no enlêvo do momentâneo e dá a sensação de que se não repete $e$ de que sempre principia. Vivendo de emoções mutáveis e fugitivas, as suas criaçc̄es são normalmente variadas, pouco se repetem e apre. sentam-se frequentemente como a expressāo de temas de ciclo completo, definido e terminado. São os poetas do concluso e do finito, do verso perfeito e do pensamento claro, cujas concepçōes se podem quase sempre traduzir facilmente pelo discurso da prosa.

A conformação de Teixeira de Pascoaes não é desta índole, e 
não o é porque a sua criação poética é a um tempo expressão e descobrimento, apreensão e evasão do apreendido. A sua inspiração nunca brotou da exterioridade dos objetos: por isso the acodem os mesmos temas com renovado apelo e a sua obra, assim em verso como $\mathrm{E} m$ prosa, se nos apresenta como desenvolução e aprofundamento de uma intuição fundamental, em função da qual considera a existência e a vida. Daí, as suas criaçōes serem a um tempo obra de Arte e obra de Filosofia. De Filosofia, sim, mas há que entender em que consiste o filosofar do Poeta, pois se trata de uma filosofia que nada tem com a filosofia e com a sistematização dos cientistas. Quer isto dizer que não é filosofia do conheier nem do saber acerca das coisas, e, portanto, filosofia de abstraçōes e de encadeamentos de coerência racional. Filosofia de um poeta, em vez da conexão com a Ciência, isto é, com conceitos exatos e demonstrados, ela tem conexão com a Arte, isto é, com intuições e com imagens expressivas da realidade. Os seus fundamentos e pontos de partida não são os da experimentação e da demonstração, $€$ jamais ocorreu ao Pensador inquirir prévia e criticamente o objeto, o questionário e o método mais apropriado ao discurso do seu pensamento. Lançou-se imediata e rendidamente, não à procura mas à apreensão de infuições que se exprimiam em imagens e se the ofereciam psicológica e afetivamente como sinal irrefragável de existências metafísicas. A fatualidade que dá ser a estas existências é uma fatualidade puramente imaterial, nāo tangivel nem visível pelos sentidos corpóreos e assim como exprimem uma realidade diversa da que comumente designamos de objetiva, assim também é conhecida por via diversa da via raciocinante, ou seja a via da analogia metafórica e da expressividade das imagens.

Assim, entendida, a filosofia de Teixeira de Pascoaes não é de forma alguma implicação, síntese ou consequência de juízos e de raciocínios, porque é essencialmente desenleio do poder relacionante e compenetrativo das imagens e das metáforas, graças ao qual o Poeta-Pensador descobriu as analogias mais profundas e reveladoras, mas também as mais surpreendentes e paradoxais.

Levaria longe e seria descabido o apurar a génese desta atitude; por isso, baste-nos somente acentuar que Teixeira de Pascoaes desde jovem concebeu a existência concreta do que nos cerca como realidade indigente e neicessitada e viu o Mundo sob o ponto de vista da conexảo do presencial com 0 ausente $e$, correlativamente, mas talvez com menos intensidade e comoção, do instante com o eterno. Habituou-se, assim, a pensar que a realidade autêntica não se define pelo que está patente, na presença ou atualidade dos seres concretos, mas pelo que é virtual e latente e se situa noutra região diversa da que é fisicamente visível. O ser patente, que a todos se oferece com igual indiferença, é a coisa que está ai e dá ensejo ao estímulo 
dos sentidos; mas a realidade profunda e autêntica é dada pelo ser latente, que somente é susceptivel de ser descoberto pelo anseio metafísico servido pelo poder apreensivo e expressivo das imagens e até do mito, de que é exemplo fulgurante o poema do 'Regresso ao Paraíso'. Recordar, é vetbo próprio deste anseio, porque é pela recordação que $\circ$ ausente se forna atual e o latente, patente; por isso, Teixeira de Pascoaes foi levado a condensar na saudade a complexa fenomenologia desta visão metafísica. 'Embriagado de sombra e de solidão', e ermado no seio da Nafureza, que é 'um incêndio quimérico e longinquo', foi no 'corpo místico e velado' da Saudade que Teixeira de Pascoaes encontrou a expressão da realidade suprema e inalterável que dá 'o místico sentido na Natura', para empregar os próprios versos de alguns passos do 'Maranus', o poema da libertação e da redenção metafísica, sem par na história da nossa criação liferária. Transfigurada e sublimada de sentimento em categoria fundamental da existência, senão em princípio cósmico, a Saudade é para - Poeta o 'fio astral que prende o olhar à estrela', a essência de um

'Novo Reino da Vida, onde termina

E principia a linha circular

Da Natureza trágica e divina:.

A brevidade que me impus, e que é também impcsição das circunstâncias, não consente que eu rastreie, levemente que seja, a influência da concepção saudosista, assim na criação poética de Teixeira de Pascoaes como na reflexão do pensador de 'O Homem Universal' e na interpretação personalizante das individualidades de 'São Paulo', de 'São Jerônimo', de 'Napoleão', de superior lição para - historiador atido somente à voz sepulcral dos documentos e de incitante reflexão para o filósofo que quer desvendar os caminhos pelos quais o ser irredutivelmente individual se mediatiza e transcende. Tampouco posso entrar na apreciação do valor intrínseco da concepção e no exame da literałura, simpatizante e polêmica, que ela suscitou; mas nāo devo terminar as minhas fugazes consideraçōes sem algumas palavras acerca do que subjaz e nutre toda a obra de Teixeira de Pascoaes, ou seja a sua filosofia ou concepção do Mundo. Do pouco que dela disse se depreende com evidência que é uma filosofia que em vez de se encadear em sistema de raciocínios que se implicam, se constitui como revelação de imagens que se congraçam, e em vez da consistência efetiva $e$ da explicabilidade causal nos dá analogias metafóricas, em que o mesmo é explicado pelo outro. A uma filosofia assim constituída é insensato pedir firmeza metodológica e potencialidade explicativa, porque por intrínseca natureza somente pode dar duas coisas que são relativamente raras na filosofia dos filósofos de profissão, ou sejam, a autenticidade e a sinceridade. 
Autenticidade quer dizer que se trata de um modo de pensar e de uma conformidade de pensamentos que são a expressão nativa de uma sensibilidade e de uma mente obediente irresistivelmente ao ritmo necessário de um pensamento fundamental e virtualmente fecundo; e sinceridade quer dizer que para se exprimir, o verbo do Pénsador não ouviu outras vozes que não fossem as suas próprias, irrompentes do seu ser profundo e incontaminado. A luz da autenticidade e da sinceridade, a filosofia de Teixeira de Pascoaes é uma filosofia original, tão densa e tão irredutivelmente pessoal que nela não faz presa a garra da 'crítica de fontes' nem o método de integração nas idéias epocais e ambientais. É produto da maneira de ser de Teixeira de' Pascoaes, e somente de Teixeira de Pascoaes, e a sua comprensão é tão exigente e susceptivel que apenas se abre a quem deixa de ver no Homem o mero animal sentiente ou a exclusiva razão raciocinante para nele atentar sobreiudo como espírito que anseia libertar-se e entrar em comunhāo com o mundo imaterial dos pensa. méntos que não são a projeção mas o retorno à Natureza pura.

O saber a que esta filosofia conduz não é o saber da Ciência, que é o saber de todos, nem é um saber que se desentranhe em técnicas de domínio eficaz da Natureza. Sob o ponto de vista científico-racional é um saber inútil, por ser incapaz de explicar, de transformar ou de modificar as condições ambientais da vida humana; e sob o ponto de vista da opinião, é uma concepção pessoalissima, cuja originalidade e expressividade poética impedem que seja e venha a ser uma concepção generalizada e muito menos popular. Inutilidade prática e originalidade intransferível não querem dizer, porém, desvalia e insignificância. Nada disso. Os tempos terriveis que vivemos são de funesto pressãgio precisamente por se haver generalizado em larguissimas zonas de população dita civilizada a cegueira para o valio. so, para o qualitativo, numa palavra para o que é praticmente inútil, e constitui, afinal, a sigla própria das civilizações. Por isso, obra e pensamentos como os de Teixeira de Pascoaes, se são pobres de utilidade e de eficácia prática, possuem, sob o ponto de vista humano e civil, o valor inestimável de não deixarem desfalecer o espírito na mecanização do quotidiano e do trivial, e de lhe desvendarem regiões inexploradas da Beleza, da Fantasia, e do próprio Pensamento na difícil e rara atividade criadora, quaisquer que sejam as suas audácias, as suas transposiçōes metafóricas, as suas inconsistências míticas. Estes são os bens supremo que o Homem pode acrecentar à Natureza bruta e indiferente; e para que nem tudo seja inferioridade e incerteza nos tempos que vivemos, gozemos a satisfação de reconhecer sincera e conscienciosamente que também nos foi dado sermos contem. porâneos das imorredouras criaçōes do gênio dé Teixeira de Pascoaes". 
Este o texto que meu pai leu na noite de 31 de março de 1951 na festa de Amarante a Teixeira de Pascoaes.

O grande poeta pouco tempo mais viveria. A 3 de fevereiro de 1952, morre a mãe do poeta, D. Carlota Guedes Monteiro. Esta morte mais abalou o seu gasto físico. O poeta decaia a passos gigantes. Um cancro num pulmão vai vitimá-lo a 14 de dezembro de 1952. Foi a enterrar, no dia 16, para o rústico cemitério de Gatão. Acompanhei-o ao sepulcro, como representante da Academia de Coimbra. O caixão fôra feito de um pinheiro, em forma de lira, a cuja sombra muitas vezes o poeta descansara. Foi vontade do poeta que essa árvore se derrubasse para dela lhe extrairem as táboas do caixão. $O$ caixão cheirava a morte, a flores e principalmente a resina virgem. Depois, desapareceu nas profundas do jazigo familiar. Na campa, uma lápida que exprimia dois versos seus:

"Apagado, de tanta luz que deu;

Frio, de tanto calor que derramou".

Meu pai, doente, não poude ir ao funeral. Mas eu também era - portador da sua imensa tristeza. Só uma vez vi chorar a meu pai e isso aconteceu em Coimbra, na nossa casa da rua de São Cristovão, quando pela manhã de 15 de dezembro soube da morte de Pascoaes.

Passaram-se dois anos. Durante este período lutou para que a memória do genial poeta fosse respeitada. Reputou que a melhor tribuna seria a da Academia das Ciências de Lisboa, a que pertencia como acadêmico efetivo. Havia uma dificuldade, Júlio Dantas, o seu presidente e escritor que nada fazia que não fosse do inteiro agrado do Estado-Novo. Se Júlio Dantas não acedesse, nada feito. Por isso meu pai escreveu ao Professor Egas Moniz, já então Prêmio Nobel da Medicina, para que sondasse Júlio Dantas... Egas Moniz apressa-se a transcrever a meu pai a carta que recebera de Júlio Dantas e rezava: - "Presidirei, com verdadeiro prazer, à sessão plenária em que - nosso confrade, Prof. Joaquim de' Carvalho - por quem tenho muita estima e a maior admiração - falará de Teixeira de Pascoaes. E sempre um encontro ouvi-lo. Eu tinha falado há tempo ao Mário Beirāo para se ocupar, numa das próximas sessōes, da obra de Pascoaes. Ignoro se ele terá qualquer trabalho feito. Talvez não, porque me parece bastante tímido. Se tiver, lerá talvez algumas páginas na sessão; e não ficará mal, porque é hoje, depois de passado a emérito - Antonio Correia de Oliveira, o poeta da Academia. Se não tiver, falará sozinho o Dr. Joaquim de Carvalho. O seu talento basta para imprimir interesse a essa sessão".

A carta de Egas Moniz, datada de 14 de janeiro de 1954, que transcrevia a decisão de Júlio Dantas, dizia: - "Meu Caro Dr. Joaquim 
de Carvalho: Tudo arranjado, como verá pela carta junta. Desculpe não the ter logo sugerido esta solução. Agora estou inteiramente tranquilo e satisfeito.

Lembro a sessão plenária de 6 de maio. Convém ${ }^{2}$ Seu admirador muito amigo, EGAS MONIZ".

A sessão de homenagem a Teixeira de Pascoaes veio a realizar-se, mas não teve lugar a 6 de maio. Decorreu no dia 18 de novembro de 1954. A ela presidiu Júlio Dantas, ladeado por Egas Moniz e pelo físico D. Antonio Pereira Forjaz. O poeta Mário Beirão não afuou.

Joaquim de Carvalho, perante uma sala repleta, foi apresentado pelo presidente Júlio Dantas como 'humanista insigne, um dos mestres do pensamento português contemporâneo'.

A sua lição foi ouvida religiosamente. Toda a família de Pascoaes - irmãos, irmãs, sobrinhos e sobrinhas - estavam nas primeiras filas. Eu, também assisti à cerimônia.

Já decorreram mais de vinte anos. O texto dessa palestra só agora o faço publicar através da revista "Letras" da Universidade Fe deral do Paraná. Neste texto, meu pai desenvolve as idéias que por primeira vez revelara na noite amarantina de 31 de março de 1951. Nenhuma outra interprélaçāo sobre o poeta da 'Elegia do Amor' é mais séria, rigorosa, científica, que a apresentada por meu pai. São páginas que sempre acompanharão a memória viva do próprio Pascoaes. Nas demais interpretaçōes há sobretudo pretexto para fazer literatura, sem se analisar o centro subjetivo onde residia a originalidade poética de Pascoaes dentro do vasto panorama da poesia portuguesa. Portugal, de fato um país rico em poetas, uma nação com poetas, uma nação com poetas grandes e universais, mas apenas com um Teixeira de Pascoaes, isto é, com o poeta Éssencialmente mais poeta de todos os poetas portugueses. Mais poeta porque não se pareceu a ninguém e só foi fiel à sua idiosincrasia, a essa cosmovisão do mundo que transpōe a mera realidade para uma realidade maior assim a tornando mais fascinante, dinâmica e espiritual.

Eis o texto integral da palestra de meu pai e que humildemente intitulou "Reflexōes sobre Teixeira de Pascoaes".

Surgindo no Brasil, onde hoje se cultiva um maior amor às coisas da cultura portuguesa do que propriamente em Portugal, apenas quero exprimir os votos de que a sua publicação redunde na atração por tão excepcional poeta lusíada e que o Brasil comece a venerar a sua figura impar com a mesma devoção que nutre por um Camōes, um Antero, um Junqueiro, um Antonio Nobre ou um Fernando Pessoa. 
O estudo de Joaquim de Carvalho será seguramente um catalizador para essa nascente atração. Sempre considerei que tem sido uma terrível injustiça o ignorar-se quase completamente o valor de Pascoaes. O Brasil tem de alargar o leque das suas simpatias. A complexidade de um poeta não the deve meter medo. Também Fernando Pessoa foi uma conquista lenta, primeiro em Portugal, depois no Brasil.

O brasileiro interessado, se quer descobrir esse continente cheio de conteúdo universal que é Teixeira de Pascoaes, tem desde logo a suprema facilidade de encontrar bem frescas na impressão as 'Obras Completas de Teixeira de Pascoaes', editadas pela Livraria Berthand em 1965, com introdução e aparato crítico de Jacinto do Prado CoeIho, catedrático de literatura portuguesa da Universidade de Lisboa.

E também se descobrirá a si mesmo, o que mais interessa!

Eis as 'Reflexōes sobre Teixeira de Pascozes' de autoria de Joaquim de Carvalho:

Foi de homem simples o curso da vida de Teixeira de Pascoaes. Sem lancers e incidentes fora do comum, sem brados e rasgos de comoçāo política ou religiosa, que são os arautos mais velozes da notoriedade, sem episódios memoráveis e até sem anedotas significativas, a existência deste homem singular e extraordinário foi totalmente dominada pela entrega à sua missāo literária, no isolamento tranquilo e inspirador da sua terra natal. O que domina e prende neste homem, de viver trivial mas singular nos modos e até nos vincos fisionômicos, é a originalidade do seu genio, que irrompe irresistivelmente, sem alarde nem cálculo, espontâneo e pujante. De vida puramente interior, mas não de alma erma e solitáría, atento somente aos apelos da sua sensibilidade e ao que com eles se identificava, tudo $\in m$ Teixeira de Pascoaes é testemunho irrefragável de um espirito vivente num mundo de configuração própria, sem o centro e sem as coordenadas do mundo que nos é habifual. Dá gosto conviver pela leitura com um ser tão raro, pela autenticidade da inspiração e pela sinceridade com que se abre, sem reticência nem premeditação. Conviver com Pascoaes, insisto, é um prazer que enleva, apesar da mágua que afetivamente me pesa, porém no que vou dizer não deixarei correr a admiração sem alguns entraves de crítica nem tampouco submeterei a exposição à cadência do elogio acadêmico nem aos andaimes da comunicação erudita, aliás prematura, dada a proximidade da memória do Poeta nos nossos corações e na nossa saudade.

Desejo somente justificar com as razōes da compreensão, e não com as da história literária, (com os da análise temática ou ainda com os valores da estética, a admiração que desde a mocidade rendo 
do genio de uma obra, que considero expressão genvina da menta. lidade poética e, enquanto tal, única e sem par na nossa língua.

Desejo somente justificar com as razōes da compreensão, e não com as da história literária, com as da análise temática ou ainda com as dos valores da estéfica, a admiração que desde a mocidade rendo ao gênio de uma obra, que considero expressão genuína da mentalidade poética e, enquanto tal, única e sem par na nossa língua.

Com eistas palavras não quero dizer que Teixeira de Pascoaes seja o melhor dos poetas portugueses. Não. Longe de mim o propósito de estabelecer paralelos literários e de fazer análises estéticas em ordém a juízos de comparação, tanto mais que tenho por seguro que os grandes poetas portugueses, precisamente por terem personalidade própria e irredutivel, possuem características peculiares que os tornam os melhores em conformidade com a sua maneira de ser e com os valores estéticos do seu poeta. Colocando-me predominantemente no terreno das estruturas mentais e no das maneiras de configurar a existência, digo somente que a obra de Teixeira de Pascoaes, na totalidade e na diversidade das suas manifestações, exprime, como a de nenhum outro escritor português, a mentalidade poética, no que esta tem de genial e de extravagante, de revelador e de vazio, de enlevo e de torpor, de iluminado e de espectral. O que Pedro Nunes significa para a mente que demonstra com rigor, Garcia da Orta, para a menté que descreve com exatidão, Pedro da Fonseca, para a mente que comenta, Herculano, para a mente que reconstitui historicamente, Vieira, para a mente que explora os recursos da palavra, Teixeira dé Pascoaes o significa para a mente que poetiza. Da sua obra se não pode dizer com propriedade que se reparte pela poesia e pela prosa nem que a vasasse em generos mais ou menos diferenciados, porque tudo o que the saiu da pena é, pela estrutura mental e pelo rítmo interno, pura e genuinamente poético. Daqui, a unidade e a conexão de toda a sua obra, tão coerente e solidária, no conjunto e em cada parte, que a compreensão do sentido dos poemas somente se alcança plenamente com as enunciadas de certos períodos das prosas, assim como a genese e o discurso do pensamento do prosador somente se explicam à luz da mentalidade poética. Impõe-se por isso, que descriminemos na sua obra as raizes que lhe deram vigor, - alénto espiritual de que se nutriu, e as expressões com que se manifestou e produziu; mas porque cada um destes assuntos impōe considerações próprias, será sobre a maneira de ser do poeta que mais atentamente refletirei.

Teixeira de Pascoaes é tipo exemplar do homem isento de compromissos alheios aos ditâmes da própria consciência e do escritor devotado à realização da própria obra, ou mais exatamente, ao cum- 
primento do próprio destino. Bem nascido socialmente, independente e aliviado de preocupações do dia de amanhā, poderia ter gozado uma existência ociosa e regalada. Tudo sacrificou, porém, durante cinquenta anos de infatigável labor, ao seu destino "de maniaco escritor, sempre sentado à mesa de trabalho, com a caneta na mão", como de si mesmo disse. Daí uma obra relativamente vasta, produzida quase toda, senão toda, no remanso do seu solar de Pascoaes, onde a sua sensibilidade e a sua mente se vingaram da "banalidade" citadina", "meditando, aligeirando o espírito, que vôa à maneira dos pássaros e murmura no estilo dos regatos", (") conforme o seu dizer.

"Em Portugal, ou a nossa aldeia, esse ninho de árvores $€$ lembranças, ou a atmosférica Lisboa - a vida pensativa e a leviana" ("3), confessou; e, com efeito, a "vida pensativa", que foi a vida que viveu, não é compreensível, e muito menos explicável, sem a sifuarmos no ambiente físico e moral em que se criou, desenvolveu e se extinguiu e, principalmente, sem a radicarmos morfologicamente na estrutura mental que the imprimiu unidade.

Poeta, e somente poeta, autêntico, sincero, convicto e confiado, sem outras dimensōes que não fossem as da nativa constituição, nem por isso Teixeira de Pascoaes se furtou, como aliás ninguém pode furtar-se às categorias da historicidade, isto é não se desprende do conjunto de circunstancias ambientais $\epsilon$ epocais em que a sua obra se gerou e produziu. No que toca ao ambiente, a alma do poeta do Maranus compenetrou-se íntima e profundamente de três componentes locais: a casa em que nasceu e the decorreu a existência, com a constelação de sentimentos inerentes ao solar de família, sem aliás os imbuir de presunção aristocrática; a aldeia em que habitou, de algum modo continuação da casa solarenga, pelo eflúvio do viver simples, e, sobretudo a paisagem dos vales e serrarias de Riba-Tâmega, pela propiação de imagens e de representaçães qué $\circ$ conduziram à configuração de um mundo de fatualidade imaterial.

A casa de família, a vida rústica, e a paisagem enquanto, não constituiram, propriamente, objeto do seu sentir e do seu configurar, mas a gestação espiritual e a atividade criadora do poeta das Elegias e do Maranus é do prosador do Sáo Paulo $\epsilon$ do S. Jerônimo e a trovoada produziram-se e desenvolveram-se com a revelação de imagens aurorais e funcionais que se radicam no ambiente amarantino.

Teixeira de Pascoaes não se cansou de repetir que as raízes do seu espírito se prendiam ao Marão e ao Tâmega, mas, em rigor, não

\footnotetext{
- Năo foram encontradas pelo Or. Josquim Montezuma de Carvalho as notas correspondentes aos números presentes no texio, que no entanto, foram conservados por respeito oo original.
} 
foi um enamorado da paisagem amarantina, senão um convivente com ela, o que equivale a dizer que se entregou totalmente à intimidade consigo mesmo e com o que intuia e configurava no ambiente que o rodeava. Sem o isolamento de S. João de Gatão não é realmente explicávél a criação dos poemas da Vida etérea e de As sombras, mas a função primordial e capital do isolamento, que não solidão e ainda menos soledade, consistiu em proporcionar à consciência do poeta o convencimento de que viver é entrar em relação com o latente e com - que transcende inefavelmente a presença e atualidade das coisas. De si disse, no S. Jerônimo e a trovoada que era "outro bárbaro nado e crescido, na remota Lusitânia, entre penedos e sombras, fantasmas de névoa e de granito", e no Duplo passeio que a infância lhe decorrera "entre seres mitológicos, o rio, a sombra das árvores, a tristeza da tarde". Vivendo no isolamento não vivia só, porque a sua mente se habituara a conviver com realidades imateriais, tanto ou mais reais que as coisas patentes. "Quem não avisła a solidão, ao cair da tarde, e o silêncio, à luz da Lua? pergunta no S. Jerônimo e a trovoada e acrescenta: "Se a solidāo $\epsilon^{\circ}$ o silêncio não existem para lá das formas solitárias e silenciosas, então não existe a nossa alma - as nossas idéias e sentimentos, em síntese personificada e animada" ( ${ }^{4}$ ).

Poetar tornou-se a expressão désta apreensão e convivência com - imaterial, ou para empregar o seu próprio dizer, em "vestir de carne transcendente as idéias mais abstractas, os mais fugidios sentimentos". (") E não somente o poєłłar, senão também a própria atividade assmiladora. Ler, para Teixeira de Pascoaes, não consistiu, verdadeiramente, em colher informes para os submeter ao crisol da razão crítica, mas em se encontrar a sós com os autores da sua predileção e com eles estabelecer um diálogo intimo, que quase sempre, e a breve trecho, se convertia em solilóquio.

No qué toca às circunstâncias epocais, às leituras e influências sofridas assim como à gestação da própria obra, Teixeira de Pascoaes não foi tão expansivo como em relação às influições ambientais. $E$ possivel que o epistolário inédito e outros testemunhos venham um dia a proporcionar informes que acentue'm ou dilatem o que revelou nas páginas que deu a público, mas temos por propabilíssimo, senão seguro, que elas não afetarão substancialmente o juízo que se desprende da obra impressa.

Este juizo énuncio-o dizendo que Teixeira de Pascoaes é dos escritores que menos tarefas eruditas reclama, no que toca a fontes e correlações livrescas. As influências que sofreu produziram-se, não por imitação, isto é modelando o seu estilo $\epsilon$ o seu pensamento pelo estilo e pelo pensamento de outrem, mas por sugerência e pelo choque emocional que as leituras the provocaram, umas vezes, alen- 
tando e nutrindo o desenvolvimento de coincidências, outras vezes gerando, por contraste, a eclosão do próprio pensamento. As suas biografias de São Paulo, São Jerônimo, Napoleão e Camilo, não são, porventura, em boa parte, autênticas autobiografias, nas quais Pascoaes tanto fala de si como dos biografados impregnando a narração, se este é o termo, de subsjetividade e de correlações de estrutura poética? Por isso, coetentemente com a sua maneira de ser, e não com as exigências da crítica que procura submeter-se às determinações objetivas, os juízos enunciados nos Poetas lusiadas exprimem fundamentalmente os pontos de contato ou de coincidência com a sua sensibilidade e, principalmente, com a sua visão saudosista do gênio português.

A génese e, em parte, o teor das suas prefigurações da realidade, assim como a entrega sem reserva ao apelo da emoção e ao dom misterioso e revelador da palavra, não se compreendem cabalmente fora das correntes filosóficas, especialmente de Bergson, que há quarenta anos justificavam o regresso ao vital e ao imediato pelo valor poético da intuição e pela exce!ência da emotividadé sobre a racionalidade.

Noutro plano, ou seja o da ação política, também Teixeira de Pascoaes sentiu alguns dos mais vibrantes ideais do nosso tempo, dando-lhes até, por vezes, expressão significativa, mas se se examinarem de perto logo se notará que tais expressões são vincadamente pessoais, ou por outras palavras, descentradas, quando não aberrantes. E que as suas manifestaçōes de pensar político assim como as suas acidentais intervençōes no foro cívico nasciam com o selo da sua personalidade inconfundível e irredutivel, sem pendão de partido ou alinhamento de fileira, tão individuais e personalistas que as suas afitudes políticas constituem uma manifestação do seu ser de Poeta, isto é, de sentir e de configurar a alma do povo português, no seu passado e no seu futuro, como objeto da sua própria criação estética. Camões, Garrett, Antero e Junqueiro, não hesitaram, em certas ocasiōes, em utilizar a Poesia como instrumento de predicação ou de combate de ideais que thes eram dados na conjuntura em que viveram e até não é ousio dizer que empenharam por vezes os seus dotes poéticos como homens de partido em poemas que mal dissimulam a premeditação e a estratégia inerentes à combatividade política. Sem Camões, a vontade ao serviço do ideal imperial não teria alcançado universalidade épica, sem Garret, a sensibilidade romântica nāo seria tão diversificada e o ideal do Portugal liberal ter-se-ia mirrado no formalismo dos homens da Lei e no progressismo utilitarista dos homens de iniciativa; sem Antero, o advento do ideal socializante teria nascido falho de vibração ética, e sem Junqueiro, o sentido republi- 
cano da vida pública não seria vivido tão intensamente como castigo e reparação. Todos estes poetas foram, sem dúvida, em certas horas, poetas atentos somente ao apelo da sua sensibilidade e do seu ideal estético, mas também é fora de dúvida que noutras horas deram expressão poética a ideais que não criaram, pondo o estro ao serviço de concepşōes a que aderiram como homens de partido. Teixeira de Pascoaes, não. Jamais foi homem de partido, empenhando-se em algo que the fosse dado externamente ou alheio ao seu ser profundo, nāo afeiçoando nunca, e muito menos transplantando para a vida pública portuguesa doutrinas e instifuiçōes forasteiras. A sua mais expressiva intervenção no foro cívico está ligada ao apostolado da Renascença Portuguesa, da qual foi alma e verbo. Este movimento, iniciado no Porto em 1911, não se compreende sem os anelos de renovação desentranhados pela proclamação da República, mas o que - caracterizou foi não propriamente a ação política, mas a propaganda de uma doutrina que se propunha, no dizer de Teixeira de Pascoaes, "criar um novo Portugal, ou melhor, ressuscitar a Pátria Portuguesa, arrancando-a do túmulo onde a sépultaram alguns séculos de obscuridade física e moral, em que os corpos definharam e as almas amorteceram". O saudosismo foi a concepção que Teixeira de Pascoaes por então revelou e predicou como éssência e fonte donde manaria a renascença de Portugal, bastando o mero enunciado da palavra para mostrar que o Poeta não submeteu a sua mente a uma realidade dada, senão que submeteu a realidade vivente de Portugal à sua maneira de ser, transfigurando-a mediante as suas próprias criaçōes e objetivações estéticas. Camōes, Garret e Antero aplicaram por vezes os seus recursos literários a concépções políticas de objetivo estrutural e normativo, que thes foram dadas na conjunfura em que viveram. Se a expressão é deles, e bem pessoal, o expressado é de outrem, e mais ou menos conhecido e divulgado. Em Teixeira de Pascoaes, porém, não é possivel separar a expressão do expressado, a criação da objetivação, porque todas brotam da sua nativa maneira de ser; por isso, as suas incursões no foro cívico e as suas páginas doutrinárias da Aguia, da Arte de ser português e do Gênio Português põem bem à vista que Portugal the interessou como objeto ideal, por assim dizer estético, das suas intuições da existência e das suas correlaçōes espirifuais, e não como realidade estatal à qual se propusese ser prestável como político, isto é, como realizador de interesses comuns e de aspirações coletivas.

Teixeira de Pascoaes poderia coincidir ou concordar, mas a sua alma não nascera para o diálogo e muito menos para ser eco; por isso nunca deixou de ser o poeta enamorado das suas próprias emoçōes e configurações - tão poeta e tão enamorado que as suas doutrinaçōes e passadas no foro público não despertaram o receio e a 
irritação, que são o séquito inseparável da ação política que se afirma com potencial de energia e de esperança.

"Em todos os meus livros, escreveu em 1936, no prefácio do S. Jerônimo a a trovoada, não obedeci a nenhum pensamento preconcebido, a nenhuma intençāo agressiva ou defensiva deste ou daquele credo, tanto religioso, como político. Escrevendo, cedo apenas a uma necessidade espiritual de revelaçāo ou confissão. Cumpro uma lei da Vida".

Com efeito, Teixeira de Pascoaes foi escritor por ditame vital e espiritual, obediente apenas ao imperativo da sua constituição psíquica. Outros o excederam na exploração dos recursos da palavra oral, no significado das concepşōes, na multiplicidade de dotes, na operosidade do trabalho, tais um Vieira e um Rui Barbosa na eloquência do verbo, um Camões, na expressividade dos sentimentos, um Gil Vicente, na ingenuidade da inspiração lírica e no arrojo da sua alma de guerrilheiro, um Garrett, no viço e floração da sensibilidade, um Camilo, na fecundidade da imaginação, um Téffilo, na obstinação de todas as horas, um Oliveira Martins, na presunção $E$ na audácia do talento. O paralelo da estesía poética permitiria ainda admirar noutros poetas, mais vivamente do que em Teixeira de Pas. coaes, a musicalidade do ritmo, a modelaçāo das imagens, a ênfase do verso, a comunicabilidade dos estados de alma, as inquietudes de consciência e o sentido da vida fecunda, exultante ou evanescente. Por mais longe e fundo, porém, que se leve o paralelo com a morfologia da sensibilidade e com a diversificaçāo e expressividade da estesia, penso que se Teixeira de Pascoaes tem parceiros na autenticidade e na sinceridade da inspiração ninguém o igualou na virtualidade genésica da palavra e da metáfora, graças às quais o seu espírito criou um universo de factualidade poética que se lhe tornou habitual e dentro do qual se produziu e objetivou toda a sua obra, de poeta e de prosador. Na sua mente, poesia e realidade, intuição e expressão compenetram-se íntima e inseparavelmente; por isso, o poetar de Teixeira de Pascoaes não foi música nem estatúária, virtuo. sidade ou artifício, e muito menos espetáculo, e passatempo, mas confidência e, sobretudo, revelação, em consequência da sua maneira de ser, que consistiu em estar poeticamente no mundo e, portanto, em nāo dirigir a mente para o mundo, já como lugar - onde de coisas práticas, já como expressão coerente de conhecimentos exatos. "O poeta, é um enviado, escreveu numa página dos Poetas lusíadas. Ele vem ao mundo afirmar as superiores Potestades que misteriosa. mente presidem ao drama da Vida e lhe dão um sobrenatural sentido. Ele vem sublimar o vulgar, revelar o grande que as pequenas coisas escondem, converter o ruído em harmonia em melodia. Só ele deu 
uma alma divina ao corpo bruto da natura, completando a obra de Jeovah".

Esta página, que somente um poeta que o fosse intrínseca e exclusivamente poderia escrever, mostra bem a indole e o teor da mentalidade poética. Ao contrário do sábio e do homem prático, a mente do poeta que o é radical e constifutivamente, não entra em contato com as coisas, senāo que as coisas é qué entram em contato com a mente do poeta e sofrem pelo contato uma estrutural transfiguração. $E$ que, verdadeiramente, a mente do poeta não se ocupa das coisas como elas são, mas das vivências que as coisas despertam. Por isso, enquanto o homem de ciência se esforça por dizer como são as coisas no seu comportamento concreto e até, às vezes, o que elas são objetivamente, isto é, para todo e qualquer ser dotado de razão lógica, o poeta, que o é intrinsecamente, dá-nos, pelo contrário, a impressão subjetiva que o contato das coisas the suscita. O sábio, dá-nos o resultado da experiência criada, conduzida e expressa pela razão lógica, e tanto mais rigorosamente quanto mais a traduzir na linguagem das relações quantitativas; o poeta, dá-nos a vivência de uma experiência subjetiva, conduzida pela emoção e expressa pela imagem e pela metáfora, e tanto mais original quanto mais se traduzir por forma pessoal e inconfundivel.

Quer isto dizer, que o poeta nāo pode ser pensado sem o objeto da sua poesia, isto é, poeta e poesia têm de ser pensados na relação que mutuamente mantêm a palavra e a coisa que ela exprime. Se não erro, é esta relação que conduz à apreensāo da radical originalidade de Teixeira de Pascoaes é à sua significação singular na história da poesia portuguesa.

$\mathrm{Na}$ quase totalidade dos nossos poetas é manifesto o sentido realista. Com maior ou menor adaptação, estão no mundo da ciência ou no da experiência de toda a gente. Assim, Gil Vicente, situa a chacota, a crítica e a parénese no mundo trivial e alegórico do homem medievo; Camões, aliás coerentemente, situa a epopeia da vontade resoluta no mundo da física aristotélica e da astronomia ptolemaica, tidas por expressão exata da realidade; Antero, sifua o ideal da aniquilação da vontade como termo das dores da consciência num Uni. verso que, após Eduardo de Hartman, pensava que era metafisica. mente coerente com a ciência moderna; e outros poelas, situados na experiência do mundo quotidiano, transmitem, dentré outros estados, a evasão de dadas circunstâncias ou de certos momentos, ou se entregam ao fluir da emotividade ou ao apelo da fantasia. Em todos, o mundo em que se sifuam é dado não só como patente mais ainda como real e consistente, pouco ou nada importando o sentido e o teor dos objetos dos seus estados, emoçōes ou fantasias, visto pressuporem 
e radicarem no mundo que thes é dado tal e qual. A poesia que nos transmitem é essencialmente poesia antropocêntrica.

Com Teixeira de Pascoaes outro é o sentido do poetar. Como acentuei, a sua obra não se compreende sem o recurso à estrututura da mentalidade poética mas não se explica totalmente por ela porque - poetar de Teixeira de Pascoaes situa-se numa concepção do Mundo não só diversa mas hostil à concepção científica. E um poetar predominantemente onfocentrico e nāo somente antropocêntrico, tanto mais que a sensibilidade e a reflexão se conjugaram para the ditarem a conviç̧ão plena de que "o destino do homem é ser a consciência do Universo em ascensão perpétua para Deus". (T) E que o homem lhe não aparecia somente como sujeito lógico, mas também, e acima de tudo, como lugar ontológico, de realidades essenciais, que estão para além do mundo da Ciência, ou seja o mundo, não do conhecimento mas do reconhecimento, o qual cria atingir mediante intuiçōes e vivências mais expressivas e valiosas do que os dados e juizos do mundo do conhecimento científico.

"Nunca me conformei com um conceito puramente científico de Existência, ou aritmético-geométrico, quantitativo-extensivo, escreveu em $O$ Homem Universal. A existência não cabe numa balança ou entre os ponteiros dum compasso. Pesar e medir é muito pouco; e esse pouco é ainda uma ilusão. O pesado é feito de imponderáveis, e a extensão de pontos inextensos, como a vida é feita de mortes. A realidade não está nas aparências transitórias, reflexos palpitantes, simulacros luminosos, um aflorar de quimeras materiais. Nem é sólida, nem líquida, nem gasosa, nem eleiromagnética, palavras com o mesmo significado nulo. Foge a todos os cálculos e a todos os olhos de vidro, por mais longe que eles vejam, ou se trate dum núcleo atômico perdido no infinitamente pequeno, ou da nebulosa Andróme. da, a seiscentos mil anos de luz da minha aldeia.

"A essência das coisas, essa verdade oculta na mentira, é de natureza poética e não científica. Aparece ao luar da inspiração e não à claridade fria da razão. Esta apenas descobre um simples jogo de forças repetido ou modificado lentamente, gestos insubstanciais, for. mas ocas, a casca dum fruto proibido.

"Mas o miolo é do poeta. Só ele saboreia a vida até ao mais intimo do seu gosto amargoso, e se embrenha nela até ao mais pro. fundo das suas sensações e sentimentos. E o ser interior a tudo. Para ele, a realidade não é um conceito abstrato, idéia pura, imagem linear; é uma concepção essencial, imagem hispostasiada, possuída em alma e corpo, nupcialmente, dramaticamente, à São Paulo ou Shakespeare". ( $\left.{ }^{8}\right)$ 
Este trecho de $\mathbf{O}$ Homem universal, tão denso de audaciosas afirmaçōes, que para a razão comum são autênticos saltos mortais em planos não só incomensuráveis entre si mas ainda incompativeis, condénsa o essencial da atitude de Teixeira de Pascoaes. Não faltam entre nós potias com o sentimento da insuficiência da explicação científica, mas penso que somente Teixeira pe Pascoaes deu o passo decisivo da ordem física para a ordem metafísica, entendendo por tal o pensamento que se situa, não nas coisas e nos respectivos comportamentos, mas no que a sensibilidade intui estar latente e para além da patência das coisas e dos seus comportamentos. Nenhum outro poeta escreveu, como ele, que "a sensibilidade poética vibra, como nenhuma outra, ao contato da Realidade e a conhece, por assim dizer, em primeirra mão. Uma verdade, quando aparece no mundo, é o poeta a primeira pessoa que a visita." Estas palavras escritas no limiar da Arte de ser português, indicam o significado e o valor que Teixeira de Pascoaes atribuiu à Poesia, e que anos depois, no $\mathbf{S}$. Jerônimo a a trovoada, tornou a repetir com estas palavras: "Sentir é viver ou conhecer, mas conhecer de dentro para fora, desde o fundo do Abismo originário. Só há sabedoria nos poetas. Só podemos vislumbrar a verdade, que é realidade humanizada, em alguns versos sublimes, e mais na sua música talvezz, que no sentido das pala. vras". A Poesia torna-se, assim, em reveladora de verdades, de um mundo adâmico, mas, como é óbvio, para empregar a distinção que faz nos Poetas lusíadas, não tem em vista "a poesia culta e perfeita", do equilibrio estético, mas a "poesa espontânea e imperfeita", isto é, "o Verbo enamorado das coisas e dos seres que nele se refletem e vivem" e que "surge nos periodos genésicos da Alma", graças "a um estado de alma criador e indefinido".

Todo o mistério da criação poética se contém nestes períodos, e - mistério mais se adensa, por assim dizer, quando se relaciona esta distinçāo da poesia com a distinção que ele também estabelece entre as duas presenças do ser: a aparência, que é apresença íntima e remota" ( $\left.{ }^{(}\right)$. Graças a estas distinçōes, que não são de maneira alguma puramente verbais, o poetar espontâneo tem por objeto apariçóes e não aparências, não consistindo, portanto, numa atividade com centro na expressão emocional ou na meiamorfose da realidade. Desentran. nha, intrinsecamente, a revelação de conhecimentos, e por isso, o poeta autêntico não encerra somente significado literário mas ainda, e principalmente, poético, porque as apariçōes se the tornavam realidades no instante em que as corporalizava pela palavra. As coisas, para Teixeira de Pascoaes, pode dizer-se, começavam a existir quando ao seu espírito se vestiam com a palavra reveladora. "A melhor ciên. cia, escreveu no 5 . Jerônimo e a trovoada (10), é a dos ignorantes inspirados - a ciência anterior aos sábios e interior e idêntica do próprio 
ser. A vida é inspiração, acrescentava, e cada ser é um poema escrito'.. "Só em certos momentos excepcionais, disse ainda noutro passo de Os Poetas Lusíadas, o poeta se torna criador de vida, rival da Di. vindade", mas nestes momentos ele se converte num "ser quase divi. no, que faz com palavras o que Deus fez com água, terra e sol".

Tanto basta para se apreender que em Teixeira de Pascoaes, a inspiração poética, apesar dé obedecer "ao derivar caprichoso da sua sensibilidade" como confessara (11), era consistente, isto é, reportava-se a realidades presentes à sua consciência de inspirado, não sendo, por conseguinte, mera excitação da imaginação. As coisas e os seres, como ele próprio escreveu, "feriam-lhe os olhos com a pancada da sua própria realidade. Mas nessa realidade, há qualquer coisa de intangivel ou além dela, que é o desespero inspirador do poeta". (12) Por isso, não foi somente de introvertido o seu poetar, porque além dé contemplar também descobria e animava. A sua mente, a um tem. po, captava e transformava, incutindo em todos os produtos da sua atividade a indole inconfundivel da sua original maneira de ser. Tudo - que tinha acesso à sua mente era recebido e modelado pela compleiçāo da sua mentalidadé, que não estabelecia fronteiras entre o sentimento e a idéia, e porque ésła ação transformadora foi constante e não acidental ou circunstancial, a atividade intelectual de Teixeira de Pascoaes foi sempré radical e intrinsecamente poética, nas estâncias dos versos como nos períodos das prosas.

No homem de mentalidade científica, o pensamento nutre-se da submissão às determinações exatas do objeto e aspira a deixar-se conduzir somente em conformidade das exigências impessoais do método; no homem de mentalidade poética, como Teixeira de Pascoaes, tudo sé passa de maneira diversa. E que, propriamente, a sua mente não entrava em contato com as coisas para lhes apreender a realidade objetiva, mas sim com o jogo de imagens e de associações que as coisas the despertavam e ao qual se rendia totalmente, com íntimo deleite sem ascese, e com a conviç̧ão de atingir conhecimentos me. diante a aparição reveladora da palavra ou da metáfora. Ao contrário do sábio, que aspira ao saber impessoal, de todos e para todos, Teixeira de Pascoaes, pelo ditame incoercível da sua nativa constituiçāo, só atendia ao que the era radicalmente original e próprio, podendo dizer-se que para ele éra real o que the despertava a inspiração e incoercivelmente se traduzia pela palavra. A procura dos enunciados inequívocos e exatos, que é para o sábio um dos tormentos do seu discorrer, não oferecia dificuldades a Teixeira de Pascoaes, que todo se entregava ao deleite da expressividade das palavras que lhe ocorriam irresistivel e iluminadamente, a um tempo com valor estético e com sentido designativo primordial e originário. "O verbo, escreveu, 
é irmão da liberdade, é propriamente a liberdade. E nele que as almas se libertam, porque se exprimem ou definem". (13) Por isso, nāo hesitou em afirmar que "qualquer opinião, como qualquer idéia, tende a transformar-se em realidade, tal o poder de encarnar que tem o verbo" (14), exemplificando este poder com a afirmação de que "a palavra irmão destruiu o Paganismo. Quem a criou foi Jesus. Criou a palavra do seu tempo; e o tempo ficou a pertencer-lhe, transfigurado em eternidade. Cada período da História é aberto por uma palavra nova. A questão é encontrá-la e agitá-la, no meio da rua". ( $\left.{ }^{(5)}\right)$

O prazer que o sábio encontra no rigor de uma demonstração ou na redução do que the é dado à objetividade e impessoalidade dos juizos, Teixeira de Pascoaes o encontrava no enlevo da criação, a qual não só o deleitava esteticamente, senāo que lhe dava a sensação de se instruir acerca do ser e das respectivas qualidades e relações imateriais.

Daqui, duas inevitáveis correlaçōes: a primeira, consiste em que - mundo que Teixeira de Pascoaes configurou, e no qual se situou habitual e irresistivelmente, não foi o mundo da objetividade impessoal e da razāo coerente e consistente; e a segunda, implicou que tivesse sido filósofo por ser constifutivamente poeta.

Deixo de lado o complexo e subtil problema das relações entre a Filosofia e a Poesia, bem como a indagação das vias pelas quais se pode chegar à conexão de uma e de outra. São temas que me desviariam do objeto principal desta reflexão. Pretendo somente notar que - poeta do Maranus foi até hoje o único poeta português no qual o pensamento filosófico se constifuiu simultaneamente com o poetar, ou, por outras palavras, não foi um poeta que deu expressão estética a pensamentos anteriores ao próprio acto dé inspiração e de criação literária. Em Antero de Quental, considerado, e justamente, o mais filósofo dos nossos poetas, impõe-se que distingamos o acto ideatório do estado pcético, ou por outras palavras mais explícitas, o seu poetar incidiu sobre penuamentos anteriormente pensados, a ponto de ser possivel assinar, aquém e além, as páginas de Proudhon, de Vera (Hegel) e de Eduardo von Hartmann, que lhe subjazem. Em Teixeira de Pascoaes nada de análogo se passa, porque o seu filosofar coincidia com o próprio poetar; por isso, a sua filosofia exprime-se mais e melhor por imagens do que por conceitos $e$, correlativamente, - seu poetar teve normalmente densidade poética, isto é, aspira a dizer algo acerca do objecto sobre que se exerce. Este facto, que julgo solidamente estabelecido, desentranha várias consequências, bastando acentuar somente a não-descontinuidade entre o acto ideatório e o estado poético, e, portanto, entre o poema e o pensamento que ele expressa. Poesia e inténcionalidade, expressão e expressado, constituem, inseparavelmente, a resposta da sensibilidade e da mente 
de Teixeira de Pascoaes às solicitações e sugerências da existência, em conformidade com a sua nativa maneirade ser e de se exprimir.

Sem embargo da intima conexão que as conjuga, pode refletir-se separadamente sobre a poesia $e$ a filosofia, considerando-as como as vertentes principais do seu espírito. Tais reflexōes abrem novos caminhos, diversos do que até agora segui. Não os seguirei, porém, pelo menos por agora, mas não quero terminar a reflexão que me propus sem condensar em breves períodos o meu juízo acerca do poeta e do filósofo.

Teixeira de Pascoaes foi um poeta autêntico, puro e confiado: autêntico, pela absoluta sinceridade da inspiraçāo; puro, peío desinte. resse, isto é, sem mancha de compromisso e de empenho, salvo com o que the ditou a sensibilidade, que na Arte como na Vida abominou as intenções e prescrições coercivas; e confiado, pela entrega com que todo se deu ao seu destino de Poeta. E, por vezes, um poeta difícil, mas não arcano, exigindo um esforço $e$, sobretudo, uma altura que impedem que boa parte da sua obra poética se torne popular. No entanto, é e será poeta de sempre e para sempre, pelo enlevo do lirismo e pela compenetração metafísica.

Pelo ditame da sua constituição mental, Teixeira de Pascoaes deu-nos uma visão poético-metafísica da realidade, que é propriamente uma mundivivência pessoal, dado que os setes e aconteceres da Natureza e da História são sentidos e não são explicados nem mesmo revividos na sua realidade concreta. Com ser pessoal, insubmissa e até hostil à sistematização racional, de teor difuso e volátil, como é próprio de quem totalmente se entrega ao deleite da liberta. ção espiritual, sem olhar para o valor explicativo ou prático dos pensamentos, não pode dizer-se que a sua visão do Mundo seja caprichosa, arbitrária e volúvel. Não tem, nem podia ter, a arquitetura de um sistema, dentre outras razōes pela que expressivamente deu nos Poetas lusíadas ao escrever que "a autêntica poesia é composta sem preocupações plásticas ou ideativas, porque tais preocupações resultam duma queda da inspiração e estabelecem logo uma distância entre o sentimento e o seu corpo". Não obstante, o desenvolvimento do seu pensamento como que assenta algumas intuições fundamentais, cujo alento e ritmo atuaram à semelhança dos princípios condutores das sistematizações racionais, dando relativa coerência e compatibilidade ao teor das congeminações. Dessas intuiçōes, esparsas ao longo da sua obra e se condensam com mais concisão no que subjaz aos parágrafos de A minha cartilha, ainda inédita e de evidente intenção, não direi sistemática mas coordenadora, importa atentar nas de estrutura nuclear e de potencialidade desenvolutiva. Se não erro, são quatro as intuiçōes fundamentais. 
A primeira, consiste na dualidade irredutível do mundo, ou seja, - mundo da "existêneia, ou da ciência, ou da razão", e o mundo da vida, o qual descreve para além da razão "a sua órbita fantástica, ou poética ou irracional". ("7) O mundo da existência real, que é o mundo da Ciências, têm uma área que "principia e finda no reino mineral. A árvore é já para os olhos de um poeta", diz no S. Jerônimo e a trovoada, acréscentando neste mesmo livro, que este é o mundo da razão "essa triste emparedada", que "é uma faculdade técnica ou mecânica, fábrica de raciocínios minerais. Ignora a idéia alada e viva que, subindo, ultrapassa os limites da Existência". (1s) Para a sua mente de poeta, o mundo autêntico é o mundo da Vida, que é também o do Espírito, porque "a matéria criada é um reflexo do Espírito criador". (19) Esté mundo autêntico, não é para todos, como o mundo da Ciência; é somente de "certos poetas já fantasmas ou convertidos, pela dor, na sua própria sombra deslumbrada. A dor, acrescentava, de tal modo nos apura a consciência e a torna cristalina, que nela se intensifica e resplende a Luz éspiritual, emanada de um sol oculto". $\left({ }^{20}\right)$

A segunda intuição reporta-se à realidade que nos cerca, conferindo-lhe uma hierarquia qualitativa de fins sucessivamente mais valiosos. "O que єxiste, não existe para si mesmo, mas para outra existência que lhe é superior em qualidade, escreveu nos Poetas lu. síadas. Eis porque os corpos materiais são transitórios e passageiros. O mineral, por exemplo, existe para o vegetal; o vegetal, para o animal, tornando-se humano, existe para o espiritual, que se torna divino". A hierarquia dá-se no sentido espiritual crescente, concebendo-a somente em relação aos fins dos elementos que constifuem o Universo, e não em relação ao Universo no seu conjunto, "porque sendo ele infinito, exclui qualquer idéia de movimento" (21).

A terceira infuição atribui à realidade autêntica, que é espiritual, uma força intrínseca mais intensa do que a natureza extensiva do espaço em que ela se manifesta. Implica esta infuição a ação a distância e como que a irrealidade do espaço, porque se cada ser ou corpo é intrinsecamente uma força, ou mais propriamente uma forma, ou antes uma alma, a força de cada ser é simultaneamente presente em vários lugares. Daqui, a visão imaterialista, que se the configurou num vago energitismo que torna a vida humana "uma fuga para além de tudo" e confere a "todo o gesto anti-animal um valor transcendente". (22)

Finalmente, a quarta intuição concretizou-se na concepção da Saudade, não só como expressão suprema do gênio português senão ainda como a "própria alma universal, onde se realiza a unidade de tudo quanto existe", como escreveu em o Espírito Lusitano. 
Esta é a mais original concepção de Teixeira de Pascoaes, a que the valeu mais notoriedade e a correlata sequela dos aplausos fervorosos e das reservas perspicazes.

Levaria longe a análise da concepção saudosista, pela multiplicidade de' problemas que suscita, pelo que me referirei somente ao que mais importa à respectiva génese e significado.

Como se depreende de numerosas referências, Teixeira de Pascoaes foi lévado à concepção da saudade em virtude da conexão que estabeleceu entre a Lembrança e a Esperança, as quais, como diz nos Poefas Lusíadas, que é o livro onde se encontram as mais significativas páginas sobre esta concepção, "são as íntimas energias que trabaIham o ser". (-5) A Esperança é o elemento ativo e criador; a Lem. brança, é o elemento que dá fixidez e corpóreo relevo à criatura", sendo a Saudade a consequência da compenetração da Lembrança e da Esperança, "casadas e excedidas num além de misteriosa e religiosa ansiedade, como diz no mesmo livro dos Poetas Lusiadas ("4)

Não pode dizer-se que Teixeira de Pascoaes haja sido totalmente original ao estabelecer a correlação da Lembrança e da Esperança, pois Santo Agostinho, pelo menos, já a havia estabelecido nas pági. nas vividas do livro $X$ das Confissóes. E possivel que Teixeira de Pas. coaes não tivesse lido estas páginas, quando pelos anos de 1911 se the prexisou com mais relevo naturais a concepção da Saudade. Leu-as, sem dúvida, mais tarde, na época da elaboração do seu "Santo Agostinho", mas tivesse-a ou não lido, entre o apologeta das 'Confissōes' e o poeta do 'Regresso ao Paraíso, que é o poema da consciência que $s \in$ sente religada ao espiritual mediante $o$ invisível e 0 inefável, há pelo menos, esta diferença fundamental: o apologeta, encontra a conexão da memória e da esperança na mediação de Cristo, isto é, na santidade, e o poeta, encontra-a na mediação da Saudade, isto é, a plenitude da consciência pela compresença da ausência, ou a vida vivida, e do desejo, ou a vida a viver. Mediante a Saudade, o poeta sentiu a compresença dé dois estados que a sua sêde de individualidade e a sua fome de omnitude solicitavam: se a consciência saudosa é, sob certo aspecto, idêntica consigo mesmo, porque não é uma consciência que de outrem se receba, sob outro aspecto é consciência do diverso, por também ser uma consciência que se reporta a seres e essências que ainda se não tornaram atuais ou existentes.

Tanto basta para se notar que a concepção da Saudade não de. sempenha na mundivivência de Teixeira de Pascoaes algo de semeIhante à essentia atuosa da substância na concepção de Espinosa, porque a Saudade é intrinsecamente, para o Poeta, a maneira pela qual ele intui na consciência o universal e ao mesmo tempo modela o 
universal em conformidade da sua maneira de ser, além de lhe dar a mediação entre a ausência e a presença, o passado e o futuro. Por isso, a Natureza, na intuição de Teixeira de Pascoaes, nāo é o teatro indiferente e anônimo da causalidade necessáría, mas o lugar onde sé dão, como que orgânicamente, as essências e impulsos imateriais. Daí o energitismo que pulsa espiritualmente em toda a sua obra e cuja sugerência mais bela e significativa se contém nos versos famosos da imorredoira Elegia do amor:

\section{Cada folha que tombava Era uma alma que subia.}

Tal é, em descarnado resumo, o que se me afigura nuclear na individualíssima e irredutivel maneira de ser de Teixeira de Pascoaes. As suas intuições e configuraçōes da realidade e das personalidades históricas de que se ocupou pouco dizem à mentalidade que somente obedece às exigências racionais do rigor e da exatidão. Como de todos os grandes poefas, pode dizer-se que o seu pensamento foi graluito e metafórico, tāo gratuito e metafórico que se não deixa cingir em conceitos claros nem encadear em juizos coerentes e consistentes. E um pensamento poético, mas como tal não é um pensamento vácuo e inútil, porque nos dá duas coisas indispensáveis à vida do espírifo: a primeira, consiste na revelação de qualidades e de valores que estāo fora da inquirição da mente éstritamente lógica, sem as quais - banquete da cultura não tem beleza nem enlevo transfigurar; e a segunda, consiste na libertação da consciência estética e intelectual. E que a cultura dé um povo não se constitui com a estratificação e com a rotina de formas, de fórmulas e de locuções; porque vive e se nutre somente do ar puro, sádio e renovador, da indagação original dos seus sábios, da reflexão independente e audaz dos seus pen. sadores, do simbolismo e alada fantasia dos seus poetas e artistas e dos vasgos e iniciativas dos seus homens práłicos. Ninguém como Teixeira de Pascoaes, no século em que vivemos, arrebatou o espírito português às anônimas e sempre atuantes forças da estratificação da Beleza, da rotina da locução e da inércia do pensamento, opondo-lhes a transfiguração da sua arte, a pujança do seu gênio criador e a suge. rência das suas intuições primordiais e entravas. Honrá-lo, é dever da inteligência que se respeita e mandamento da consciência cívica que se preza. 
pensamento pośtico, tas como tal กล̃o ś um pensanento vásuo e lnútil, porque ros dá duas colsas indispensávels à vida do espirito: a primot ra, co:alste an revelną̃o de quallades e de valomes que cst.̃o fora de Inquirição da tente estrictaante lóg1ca, sem fo qualo o banquete

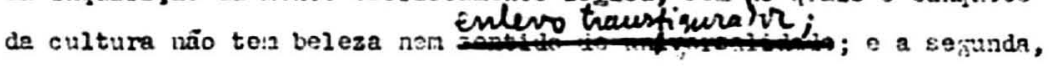
consiste na libertação da consolencia sstética e inteloctual. É cue

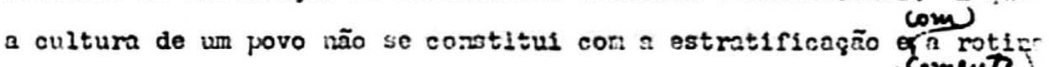
de romes, de rómilics o de loctiqões; yorg̣!e vive e se nutrexdo er piro, sàdio e renovador, da indagnção oririnal dos seus sáblos, sta uflesion

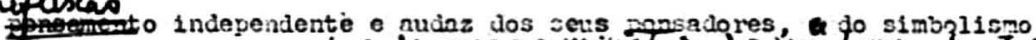

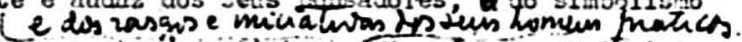

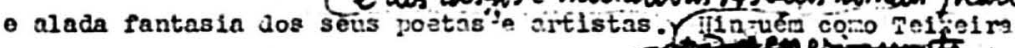

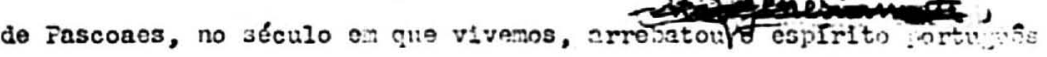
ds anónimas e cenpre ecturates forges is estratificagro is jelsz?. in

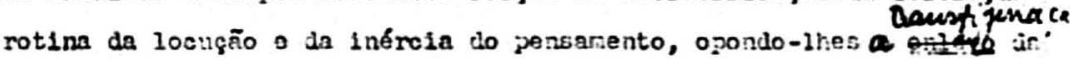

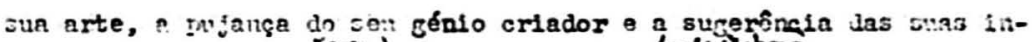

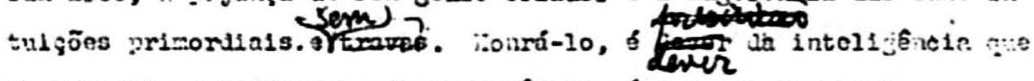

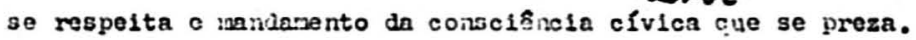

\section{paquin de Carrallis.}

